\title{
Government Policy Approach to Environmental Conflicts among the Niger Delta Communities: Implication to 2015 and Post 2015 Sustainable Development Goals
}

\author{
Okafor Samuel 01, Okafor Joachim C 2 \\ ${ }^{1}$ Department of Sociology/Anthropology University of Nigeria, Nsukka, Nigeria \\ ${ }^{2}$ Department of Political Science University of Nigeria, Nsukka, Nigeria \\ samuelokey200@gmail.com, Chukwma.okafor@unn.edu.ng
}

\begin{abstract}
The present study is focused on the public perception of government approach to the environmental challenges in the region of Niger Delta and its implication to environmentally-related conflict resolution and inclusive society. Four states were randomly selected while eight local government areas, 24 communities and 500 respondents $\left(18^{+}\right)$were randomly selected for data collection. Our evaluation and analysis were focused on the public perception of the government policy approach in resolving the environmentally-related conflict in the region, support to this approach and the likelihood of youth involvement in violent agitation in the region. From our data, we pinpointed and demonstrated the weaknesses and unpopular nature of the dominant policy approach in the region as well as the latent energy of environmental conflict in the region. For policy relevance of the study, we ran a statistical cross examination on prevailing sociological issues in the region relevant to sustainable environmental and conflict resolution policy in the region. Our study established some factors relevant to inclusive society policy in achieving sustainable peace in the region such as public perception of government approach to their environmental challenges, socially-inclusive mode of consultation, age etc. in view of the strength of our data, the findings and suggestion of the study will help the Nigerian government to the threshold of people oriented and sustainable policies in dealing with the ceaseless conflict agitations in the region. The study aims to contribute in the current social scientific literature, the point of individual involvement in environmental conflict in the Niger Delta region of Nigeria.
\end{abstract}

Keywords: Environmental degradation; socially inclusive policy; Conflict; Niger Delta, SDGs.

\section{Introduction}

Environmental hygiene is one of the vital aspects of human existence and survival, making it, the pillar of argument about the wellbeing of the inhabitants of the oily rich regions of any part of the globe (Onwubiko, Azizan, Khairuddin \& Othman, 2013). Putting into consideration, most of the developing nations with oil deposits have majority of their population heavily dependent on the natural environment. For instance, according to UNDP $(2006,2017)$, the environment is very important for the Niger Delta people of Nigeria (comprising of nine states which include, Abia, Imo, Rivers, Delta, Bayelsa, Cross River, Edo, Ondo and Akwa Ibom States) where $60 \%$ of the population depends on the natural environment, living and non-living - for livelihood. In essence, many developed nations such as the United States of America, Sweden, Norway, etc. who in principle and practice understand the implication of endangered environment to the inhabitants of the oil exploration axis and the government in general, take precaution in decisions regarding methods of drilling and perhaps the alternative ways of managing the sustained environmental pollution.

This has helped many of these developed nations to manage the surfaced and unforeseen environmentallyrelated conflicts in their oily rich regions. The situation in pursuit of already set pace is required anywhere in the world for the general appreciation of the lives and rights of the inhabitants of the oil producing regions of the world domestically and globally. Oil revenue has revitalized the world economy for decades now after it appeared to be more lucrative and reliable wealth in terms of prediction and exploration. This has made it the world hottest treasure to be pursued by all nations irrespective of the location and position. Nigeria is among the nations in the world where the deposit of crude oil and gas has change the economic structure of the government with its associated socio-political implications. The appearance of crude oil in the Nigerian socioeconomic activities was not without certain effects and impacts on the nation as a whole. The discovery of oil in Nigeria in 1956, shifted the paradigm of economic policy from agriculturally emphasized policy, to oil emphasized policy leaving other source of revenue to a minute structural position (Amnesty International, 2009). On environmental aspect, the presence of crude oil exploration in Nigeria has left behind its trail, enormous impacts, that had questioned. 
The benefits of oil exploration in Nigeria to the poor masses and the host environments chief among these socio cultural and environmental impact is that of oil spillage/pollution. According to Steiner (2008), and Zabbey (2009) oil spills in the Niger Delta have been extensive, difficult to assess and often under-reported. Indeed, the bulk of oil companies operating in Nigeria deliberately under-report the extent of oil spillage in Nigeria to limit their legal liability for commensurate claims and compensations from oil spill damage (Steiner, 2008; Zabbey, 2009). Yet, it is existing fact that oil spillage is one of the worst impact of crude oil exploration in Nigeria especially, among the host communities, as it is affecting the majority of the poor masses. This of course, has reflected on the covert and overt environmentally-related conflicts in the region. Records, between 1976 and 2001 alone indicate that 6817 oil spills occurred in Nigeria mostly from equipment failure and other preventable situations. This resulted in the loss of approximately three million barrels of oil (UNDP, 2006; 2017). According to Shell (1999), from 1990 to 2007, there has been a total volume of 284,000 barrels of oil spills. Among the notable oil spillage in Nigeria are 11 oil wells. Government and other interested agencies ought to set up environmentally relevant infrastructures to encourage selfemployment and productivity in the region, to gradually neutralize the mind of the youth from dependency on the gift from the government and other organizations. The consultations in the region, the policy initiation these entire incidences were expansion of dangerous chemicals against the aquatic habitats and the natural environment on which the human inhabitant depends for their survival in the region.

The UNEP (2006) summed up the impact of oil spill on the environment in the Niger delta region as follows: High mortality of aquatic animals, Impairment of human health, Loss of biodiversity in breeding ground, Vegetation hazards, Loss of portable and industrial water resources, Reduction in fishing and farming activities, and Poverty, rural underdevelopment and bitterness among the host communities. Acquisition of land by the oil firms for pipeline right of ways, flow lines, flow stations and gas glaring sites normally engendered acrimony between oil firms and host communities on one hand, and among the host communities. This, latter escalated to the level of arms hostilities among the youth in the region with major focus on kidnapping, destruction of pipelines etc. Thus, engendering conflict and instability at micro and macro levels (UNEP, 2006; 2017). According to Adalikwu (2007) evidences show that there is a high level of moral bankruptcy among the youths in the oil hub of the nation (Niger Delta) among which are dwindling of the cultural values among the youth and high level of violence and crime in the region. According to Ukeje (2001) and Yakubu (2017), the youth unrest in the region till date is directly and indirectly connected to the impact of crude oil exploration in the Niger Delta region, where the youth are used as tools in engendering conflicts and perpetuating all manner of crimes. In response to the ever-growing environmental degradations and the public outcry in the Niger delta region of Nigeria, the United Nations and the Nigerian governments have put in, some level of efforts. To resolves both the issue of environmental pollution and the outcome of it such as youth restiveness in the region and the arms struggle against the government (Nduka, \& Orisakwe, 2009; Obafemi, Eludoyin \& Akinbosola, 2012; Agunobi, Obienusi \& Onuoha, 2014).

However, the efforts so far have yielded either minute result or at worst have become total failure as the indices of reactions to the environmental pollution such as violence and arm-struggle against the government is still the order of the day in the region (Ajodo-Adebanjoko, 2017; Ajero, etal, 2016; Shehu \& Ali, 2015). In essence, a number of policies and strategies adopted so far by Nigerian government to resolve the environmentally related violence in the Niger delta region mostly ended without any positive result. Of paramount interest is the United Nations' Sustainable Development Goals in principle and the subsequent incorporation of such in the domestic policies without empirically informed strategies. In view of the goal 16 of the SDGs [Promotion of Peaceful and Inclusive Societies for Sustainable Development] and the follow up policies by the federal government, which reflected in the government, developing and implementing a sustainable action plan to stabilize and develop the Niger Delta; Ensuring environmental sustainability within the Niger Delta Region and Reducing Conflict-related deaths per 100,000 population to $10\{2015\} ; 6.65$ $\{2020\} ; 0\{2030\}]$ to match this goal (Federal Government of Nigeria, 2017); there is yet to be sociallyinclusive environment and conflict resolution policy strategy by the federal government of Nigeria. Niger Delta region before 2015 was expected to have witnessed at least a peaceful environment and sincere commitment on the side of the federal government in reducing environmentally-related conflicts and deaths. However, the situation is deteriorating even though the federal government and their multinational oil corporation allies decided to shield the realities in the region from public media search light. 
The security situation in the region, the environmental degradation and poverty in the region worsened from, 2015 in the face of empirically flawed policy strategies and socially isolated policy framework (UNDP, 2011; 2017; Ede \& Edokpa, 2015; Enetimi \& Izah, 2017). The concern of the present study and perhaps, the puzzle set to solve through the study was to understand and put in perspective, the factors that likely predict the youth involvement in violent struggle in the region in cognizance of the current government approach to environmentally-related conflicts. Consequently, the study focused on exploring the implication of the current approach to some collaborative efforts in putting to an end, the ceaseless violent struggles and youth restiveness in the region in order to inform timely and people-oriented policies in the region for the actualization of the post 2015 Sustainable Development Goals agenda.

In view of the issues raised above, the study was designed to answer the following questions:

- Does meeting with the leaders on behalf of the affected people function as a viable strategy for lasting peace in the region?

- Are the people willing to support the government based on the current approach by the government to resolve the problem in the area?

- What are the factors that can likely predict involvement in violent struggle in the region?

- What are the factors relevant to sustainable conflict resolution policy in the region?

Niger Delta Region and Nigerian State in the Face of Environmental Degradation and Conflict of Interests: Oil explorations in Nigeria, which began in large commercial scale in Oloibiri in the present day Bayelsa state in 1958 has no doubt contributed immensely to the development of Nigeria (Nworu, 2017). However, the most pathetic about the scenario above, is the level of environmental degradations that have been experienced in the Niger Delta region by the inhabitants, who have continued to bear the burden of oil explorations over these years resulting to the on-going covert and overt conflict (Muhammed \& Demirci 2015). The Niger Delta region, is a geographical location in Nigeria that has been marred by the forces of divergence interest, where three conflicting irreconcilable interest such as the Nigerian State, the multinational oil corporations and the oil bearing communities are struggling for who gets what, when and how since the oil exploration began in the 1950's (Isike, 2005 in Okumagba, 2012). This struggle has brought to intellectual limelight, the growing agitations against the deplorable environmental degradation that has affected the ecosystem of the people. The agitation from the people of this area is majorly being assessed in the light of public perception concerning government approach in reducing the effects of oil explorations on the environmental wellbeing of the people and how environmental laws guiding the activities of the multinational oil corporations operating in the region are not being implemented and are fraudulently being abused (Yakubu, 2017; UNEP, 2006). Over the years, oil exploration has caused more damage to the host communities than the assumed benefits from the federal government of Nigeria. This is evident in the level of destabilization of the peace and progress of the predominantly agrarian and fishery communities in the region.

Contaminated streams and rivers arising from massive oil pollutions, forest destruction and biodiversity loss in the region has brought on the inhabitants, abject poverty and displacement. As Kadafa (2012) put it, it is unsustainable oil exploration activities that has rendered the Niger Delta region one of the five most severely petroleum damaged ecosystems in the world. Ibeanu (2006) was of the view that the scenario in the Niger Delta region has been a clear lesson of the dialectical relation between affluence and affliction, security and insecurity, wealth and poverty, development and underdevelopment in equal measures. The flagrant Oil spillage from the major multi-national oil companies, pollutions and the continued flaring of gas into the atmosphere in the region has been the greatest threat to human lives and other living creatures including water quality and vegetation in the area (Enetimi \& Izah, 2017). While many have died by the bullets of the federal government troops and the militants' internal hostilities, more have lost their lives from the on-going contamination of the drinking water, air pollution and other environmental hazards accompanying reckless oil exploration in the region. The political economy of the Nigerian state that has been anchored on the oil production and its sustenance, has led to the militarization of the region by the Nigerian state. To ensure the securitization of oil production from the region, different security operations have been launched such as operation Delta Safe, Pilo shield and in recent times, operation Crocodile smile. To this end, the militarization of the region by the Nigerian state following the preponderance surge in the activities of the militant groups, have resulted in the violation of human rights in the region (Okumagba, 2012). 
Furthermore, arising from lack of participation and good governance deficit in the region, the region has been described as conflict trap and thickening time bomb that has the capacity to exceed its current crisis level if not checked. Luqman (2011) submitted that despite the establishment of policy options through institutional frameworks to arrest environmental insecurity and myriad of development challenges facing the region, these policies were motivated by politics, fear, cheered optimism intrigue. Among the policy strategies adopted by Nigerian government to resolve environmentally-related violence in the region are, using the community elders in the region to put the youth under check, giving out certain amount of cash for amnesty, citing a number of projects, using military might to intimidate and silence the people in the region, etc. With close look at the situations and circumstances informing the behaviours of the sociological majority in the region, all these methods of conflict resolution are obsolete, out-dated and out of context as the modern youth in the region are more sophisticated and observant than the imagination of the federal government of Nigeria.

For instance, the case of Ogoni land revealed how government and the multinational corporations deliberately subverted the UNDP recommendation and move on the line of securing their interest against the wellbeing of the inhabitants of the region. This, subsequently, led to the environmentally related conflict, metamorphosing into agitation for self-government in the region in the current posture of the agitation owing to the inhabitants' suspicion of government body language. Another instance is the subversion of the $\$ 40$ billion made for basic Niger delta development projects in 2015. Instead of the original purpose for the money, the money was spent on re-scheduled elections in Rivers and Bayelsa states mainly on over eight thousand security personnel, specially exported to the region to quell unforeseen violence during the rescheduled elections. This again, advanced the approach to the agitation by the militants, leading to the massive pipeline destructions and the subsequent national economic shake-up. While suggesting that those policies established in form of Development Commission have fairly addressed some of the issues underlying oil conflict in the region, there are countless challenges lying ahead of the region and the Nigerian state, which ought to be put in perspective via empirical investigation in the region.

\section{Theoretical Frame Work (Frustration- Aggression Theory: Dollard et al., 1939)}

The Theoretical frame work of this study was drawn from the frustration - Aggression Theory (Dollard et al., 1939). Frustration aggression theory is a theory of aggression which states that aggression is always a consequence of frustration. It attempts to explain the cause of violence. Dollard et al. posit that frustration cause aggression and when the source of the frustration cannot be challenged, the aggression gets displaced onto an innocent target. There are many areas where aggression manifests in the society these include domestic violence, abuse, school bullying war and political violence. The frustration -aggression theory states that an individual becomes discomforted when he/she is frustrated and that the sad condition leads to aggression and violence (Abekhale \& Tor-Anyiin, 2013). Frustration is the condition which exists when a goal-response suffers interference. The failure to obtain a desired or expected goal leads to aggressive behaviour. However, aggression is not always the response to frustration rather a substitute response is displayed when aggressive response is not the strongest in the hierarchy. Frustration -aggression theory has been used to explain some level of violence and conflicts such as political violence, environmentally connected violence, youth restiveness, etc. There are four mediating factors, which influences aggression.

These are: Magnitude of frustration, Aggression cues, Arbitrariness of frustration and Cognitive and emotional processes (Dollard, et al., 1939). Magnitude of frustration is the intensity of blocking goal directed behaviour. Dollard's frustration-aggression theory explains how intense the situation can be, for it to become the antecedent to an aggressive act. In other words, being so close to one's goal and being neglected may be one act in an aggressive manner, due to the excitement and expectation of receiving one's goal. Aggressive cue can identify the aggressive reaction resulting from a barrier to goal attainment. The aggressive cue versus the neutral cues tends to enhance frustration, which leads to aggression. Consequently, frustration facilitates aggression in the presence of aggressive cues. Unexpected blocking of goals can lead to frustration and aggression. In other words, expecting a goal however ultimately being prevented from it all of a sudden explains the arbitrariness of frustration and frustration- aggression actions or behaviour. Frustration is likely to lead to aggression when an individual's emotional experiences are interpreted as negative. Attributions are made, when one experiences conflict in their environment. Hence, we tend to understand and attribute causation to this experience through emotional and cognitive processes. 
As to the principal thesis, Dollard et al. (1939) stated that the occurrence of aggressive behaviour always presupposes the existence of frustration and contrary wise, that the existence of frustration always leads to some form of aggression. Dollard et al. posit that strength of aggressive reaction depends in part on the amount of residual instigation from previous or simultaneous frustration. Minor frustrations add together to produce an aggressive response of greater strength than would normally be expected from the frustrating situation that appears to be immediate antecedent of the aggression. However, not all frustration produces over aggression, but this does not mean non-aggression. This is because being furious inside can be interpreted as non-overaggression, but this can linger on and erupt in over its manifestations at later time. An individual can be frustrated when he/she is unable to realize his/her goals or meet his/her needs. This position is still being debated because not all aggression is caused by frustration. Aggression can be caused by stress, negative effect or unpleasant emotions (Bernstein, Clark Steward, Pernner, Roy, \& Wickens 2000). Meanwhile the behaviourists hold that aggression and violence are learned behaviours.

They believe that humans learn how to behave in social interaction whether properly or improperly (Schaeter \& Lamm, 1998). In his definition of aggression, Akinade (2005) states that aggression is a behaviour that is intended to inflict physical or psychological harm on others. He maintained that aggression is believed to be largely learned. For instance, children who grew up in an environment where aggression and violence are prevalent are likely to become aggressive. Osarenra (2000) asserts that violent environment tends to affect the behaviour of the children raised in such environment. Environmentally related violence in the Niger delta region could be seen in the perspective of the frustration-aggression theory. The inhabitants of the region are mainly surviving through farming and fishing. When the pollution and environmental degradation started undermining their source of livelihood, they were forced to react to the nearest object and circumstance which in most cases started with intra and inter communal conflicts. Communal conflicts latter drew them to kidnapping where the oil expatriates became the target and later, they started closing the oil facilities. Virtually all the indigenes of the region, which are living within the region, were exposed to the dangers and the hazards of the pollution from the oil exploration in one way or the other.

This situation accumulated to the level of collective aggression towards the government and oil facilities in the regions. In turn, the collective aggression towards the government provided the umbrella for sub groups and individual atrocities in the name of reacting to the environmental pollution in the region such that the region has become the safe haven for all forms of crimes and human right abuse via the militants' activities. The reaction towards the environmental degradation in the region laid foundation of animosity among the communities in the region and between the communities in the region and the government/multinational oil corporations. This may involve weapon or no weapons but in essence, is a projection of violence. Subsequently, for years, Children were growing to believe that aggression and violence are part of the culture of the people and the ultimate way for actualizing fair treatment from the government and the multinational corporations. Meanwhile socio-economic factors such as illiteracy, hunger, disease, poverty, unemployment, stress and social isolation are re-enforcing aggression and violence in the region (Osarenra, 2000; Ortese, 2004; Akinade, 2005). In line with the aim of the present study, the frustration-aggression theory best explained the conflict situation in the Niger delta region and also is connected with the misplacement of the realities by the government and other agencies interested in the problem.

While the government is looking for the short cut and figure heads to use as an instrument to control the youth in the region ignoring, the affected people and long-term people-oriented conflict resolution policies, the affected people continue to make the efforts of the government ineffective. Neither Nigeria nor foreign donors has socially inclusive policy strategy in approaching the conflict in the region. While Nigerian officials opt to buy short-term cease-fires, such as the 2009 amnesty process and the likes, state governments spend too little in money and manpower to grow local civil society, engage core conflict issues, or adequately understand the region's problems. The masses, who are involved in the problem of environmental pollution, which initiated the conflict in the regions, are momentarily or always ignored while the leaders of the communities go for round table discussion with the government and other agencies about problems they feel little or nothing about it. After the round table meetings with big envelops, the leaders go home to calm the people down for some time as long as envelop last in their minds. When they feel they need attention from the government and other agencies. They inspire their subjects (the youth) for agitations and atrocities against the government and the multinational corporations. 
Meanwhile, the inhabitants of the region, who are directly affected in the oil pollutions leading to conflicts, know nothing about the position of the government and the multinational corporations except what the leaders interpreted to them usually to maintain their own interests. Again, the government virtually know nothing about the mind of the real people involved in the conflicts hence making blind arguments with the leaders and unrealizable recommendations. In sum, while the inhabitants of the region are reacting to the impact of the oil pollution on their livelihood, the community leaders hijack their sympathetic condition to hold government in ransom while at the same time provoking the inhabitants against the government when they feel their own interests are ignored. The government of Nigeria react to the violence in the region, using force when they feel their efforts are not being appreciated by the inhabitants in the region.

Table 1: Logical Data Framework

\begin{tabular}{|c|c|c|c|c|c|c|}
\hline $\begin{array}{l}\text { Research } \\
\text { questions }\end{array}$ & Hypotheses & $\begin{array}{l}\text { Major variables of } \\
\text { the hypothesis } \\
\text { Ind }(x) \operatorname{Dep}(y)\end{array}$ & $\begin{array}{l}\text { Empirical } \\
\text { indicators } \\
\text { variables }\end{array}$ & $\begin{array}{l}\text { Sources } \\
\text { of data }\end{array}$ & $\begin{array}{l}\text { Method of } \\
\text { data } \\
\text { collection }\end{array}$ & $\begin{array}{l}\text { Method of } \\
\text { data } \\
\text { analysis }\end{array}$ \\
\hline $\begin{array}{l}\text { 2) Are the } \\
\text { people willing to } \\
\text { support the } \\
\text { government } \\
\text { based on the } \\
\text { current } \\
\text { approach by the } \\
\text { government to } \\
\text { resolve the } \\
\text { problem in the } \\
\text { area? }\end{array}$ & $\begin{array}{l}\text { Age, duration } \\
\text { of conflict } \\
\text { experience, } \\
\text { Government } \\
\text { approach to } \\
\text { environment, } \\
\text { mode of } \\
\text { consultation } \\
\text { of the affected } \\
\text { in the } \\
\text { environmental } \\
\text { degradation, } \\
\text { etc, will likely } \\
\text { predict youth } \\
\text { involvement } \\
\text { in in in } \\
\text { environment- } \\
\text { related the } \\
\text { conflict in } \\
\text { Niger Delta. } \\
\text { Age, duration } \\
\text { of conflict } \\
\text { experience, } \\
\text { Government } \\
\text { approach to } \\
\text { environment, } \\
\text { mode of } \\
\text { consultation } \\
\text { of the affected } \\
\text { in environmental } \\
\text { degradation, } \\
\text { etc, will likely } \\
\text { predict } \\
\text { support to } \\
\text { sustainable } \\
\text { conflict } \\
\text { resolution } \\
\text { policy in in } \\
\text { Niger Delta. }\end{array}$ & $\begin{array}{l}\text { x) Age, duration of } \\
\text { conflict experience, } \\
\text { Government } \\
\text { approach } \\
\text { environment, to } \\
\text { mode of } \\
\text { consultation of the } \\
\text { affected in the } \\
\text { environmental } \\
\text { degradation, etc } \\
\text { y) Dependent } \\
\text { variable: } \\
\text { Youth perception } \\
\text { of violent struggle } \\
\text { as the viable means } \\
\text { of resolving the } \\
\text { environmental } \\
\text { problems in Niger } \\
\text { Delta region }\end{array}$ & $\begin{array}{l}\text { x) Government } \\
\text { meetings with the } \\
\text { affected } \\
\text { communities, } \\
\text { number of years } \\
\text { one has observed } \\
\text { conflicts in the } \\
\text { region, number of } \\
\text { years one has } \\
\text { lived, etc. } \\
\text { campaign } \\
\text { voting } \\
\text { y) Youth } \\
\text { cooperation with } \\
\text { the government } \\
\text { in implementing } \\
\text { the current policy } \\
\text { on Niger Delta } \\
\text { conflict. }\end{array}$ & $\begin{array}{l}\text { Primary } \\
\text { data } \\
\text { collection }\end{array}$ & $\begin{array}{l}\text { Quantitative } \\
\text { using field } \\
\text { data }\end{array}$ & $\begin{array}{l}\text { Quantitative } \\
\text { data } \\
\text { analysis } \\
\text { using SPSS }\end{array}$ \\
\hline
\end{tabular}




\section{Methodology}

The study was carried out among 5 states randomly selected from the nine states of the Niger Delta region among which are Abia, Imo, Rivers, Delta, Bayelsa, Cross River, Edo, Ondo and Akwa Ibom States. Adult males and females from the 15 to 40 years were selected from the selected five states (Abia, Bayelsa, Cross River, Delta and Rivers) using inclusive criteria such as families that have at least, a farmer or a fisher and individuals that have witness indices of environmental pollution such as oil spillage, fire outbreak as a result of oil facilities, soil contamination etc. at least once before 2017. The age categories in the study was chosen to specifically involve the active youth who are most likely to be actively involved in the on-going conflict in the region and perhaps likely to facilitate or hinder the current and future conflict resolution policy in the region. The study adopted cross sectional survey design. The choice of this design was in line with the theoretical proposition about the dominant factors in the Niger delta environment related conflicts. While the government policy approach to the situation in the region is a set of statements with qualitative and quantitative development implication. Support to these statements and by implication, its acceptability based on the realities on the ground, are subjects to attitudinal disposition of the inhabitants of the region.

In essence, for the possibility of empirical evaluation of the theoretical proposition, which is on frustrationaggression theory, in connection with the policy statement and possible realities in the region, the logic of social survey in data collection and analysis is indispensable. The study randomly selected five states among the nine states in the region. Among the 5 states are: Abia, Bayelsa, Delta, Cross River and Rivers states. According to the projected population of the youth between the ages of 15-40 in the five selected states, based on the 2006 census data, there is 5671060 youth between the ages of 15 to 40 Abia (1227906); Bayelsa (727463); Cross River (1244547); Delta (1748502) and Rivers (2322642). We adopted Taro Yamane (1967) statistical formula $\left(\mathrm{n}=\frac{N}{1+N(e) 2}\right)$ to determine the sample size of the study. Based on the population of the youth in the five selected and following the Taro Yamane statistical formula, the sample size of the study was determined to be 500. The study adopted both random and modified random sampling techniques in selecting the respondents. While the random sampling was adopted at the regional (Niger Delta), states (the selected five states), local government (the local governments in the selected states).

The communities (communities in the selected states and local governments) and the wards (the wards in the selected communities), modified random sampling was adopted in selecting the households (households in the selected wards) and the respondents for the study (youth in the ages of 15-40). All the states selected were equally represented in the study by adopting equal probability sampling technique. In each of the 5 states selected, 5 local government areas were selected using simple random sampling technique (balloting). Here, the names of the local governments in each of the selected state were labelled from which the researchers selected 5 local governments each, bringing together, 25 local governments selected with simple random sampling technique. Among the 25 local government areas selected from the five states, 5 communities were selected from each of the L.G.A using balloting bringing together, 125 communities. Among the 125 communities selected, 2 electoral wards and 2 households from the electoral wards were randomly selected bringing together, 250 electoral wards and 500 households. Among the selected 500 households, 1 respondent was selected from each of the households using modified random, sampling. In total, 500 respondents were selected from the randomly selected five states (i.e. household $=1 * 500$ (500 respondents by 500 selected households).

Electoral ward $=2 * 250$ ( 2 respondents by 250 selected electoral wards); community $=4 * 125$ ( 4 respondents by 125 selected communities); local gov. $=20 * 25$ (20 respondents by 25 selected local governments); State $=100 * 5$ (100 respondents by 5 selected states) $)$. The instrument for the study was survey questionnaire developed on ordinal scale with specific focus on the indices of violence, amnesty program in the region and other substantive issues about the violence struggle in the region including the public perception of the government policy approach in the region. The questionnaires were self-administered with some guidance from the researchers where the respondents requested for assistance. The data collected were coded and analysed using Social Science Statically Package (SPSS version23) while the research questions and hypotheses guiding the study were answered/tested with descriptive and inferential statistics such as percentages and Linear Regression. 


\section{Figure 1: Data Presentation and Analysis}

Figure 1: Distribution of the respondents by age

$\square 18-23 \quad \square 24-29 \quad \square 30-35 \quad \square 36-40$

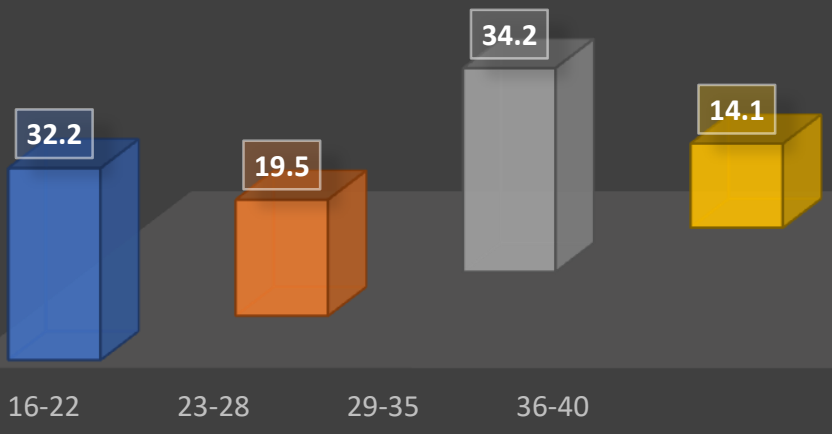

Source: Field survey, 2018.

Figure 1 displayed the age distribution of the respondents, according to the distribution, $34.2 \%$ of the respondents are in the age category of $29-35,32.2 \%$ are in the age category of $16-22$ while $14.1 \%$ are in the age category of 36-39.

Figure 2: Distribution of the Respondents by Educational Qualifications

Figure 2: Distribution of the respondents by educational qualifications

$\rightarrow$ Primary education $\quad$ Secondary education $\triangle$ National diploma $\times$ B.A/B.Sc $*$ M.Sc/M.A/Ph.D

30

1

2

3

4

5

Source: Field survey, 2018.

Figure 2 shows that among the respondents sampled, 27.5\% possessed Bachelor of Arts (B. A) and B.Sc. (Bachelor of Science), and 25.6\% have National Diploma and Higher National Diploma Certificate; while 30\% of the respondents have Secondary Education certificate $12.2 \%$ and $4.7 \%$ possess primary education certificate and M.Sc. and above respectively. 
Figure 3: Distribution of the Respondents on whether they see the Meeting with the Leaders by the Government Agencies on Behalf of the Affected as Fair and Inclusive

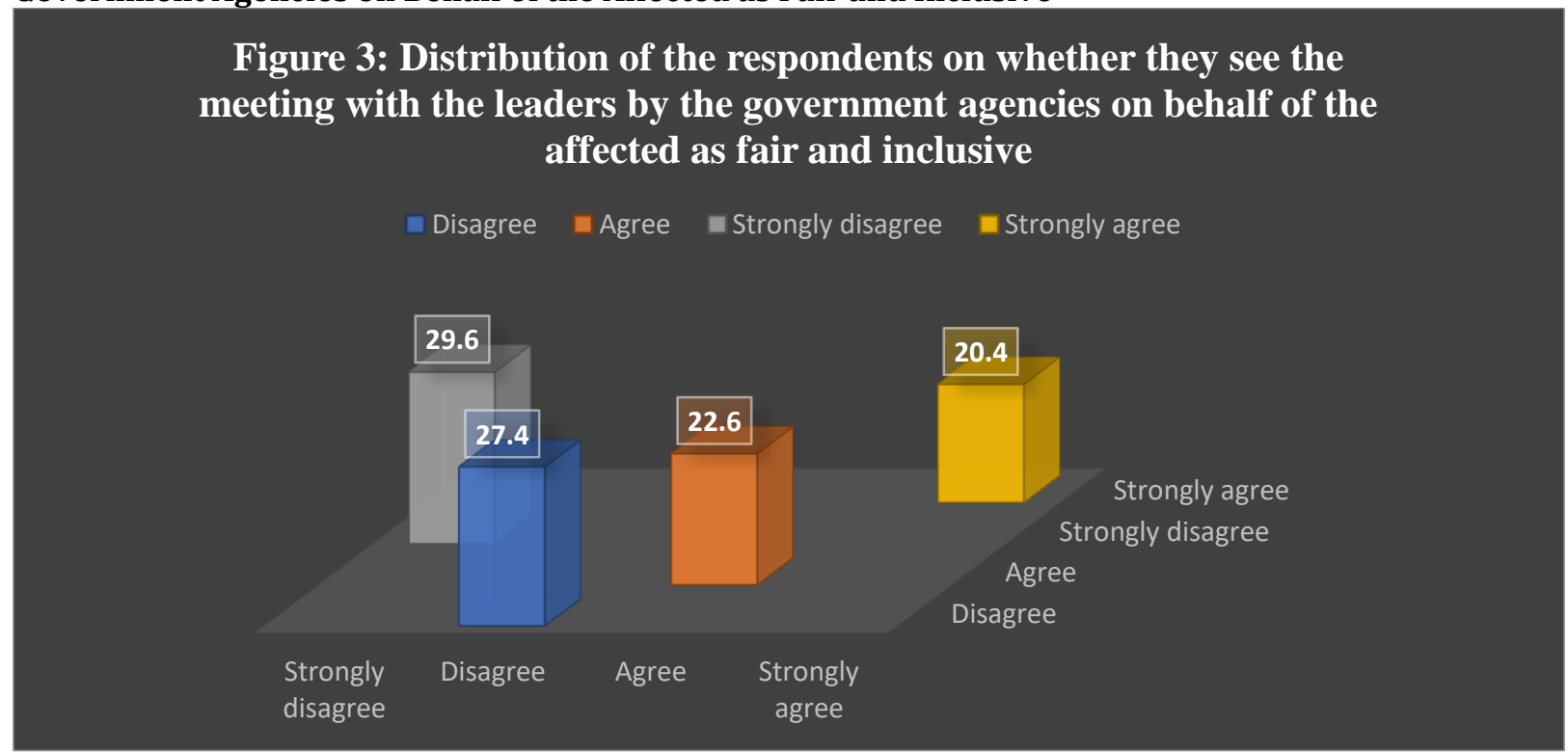

Source: Field survey, 2018.

Figure 3 is the distribution of the respondents on whether they see the meeting with the leaders by the government agencies on behalf of the affected as the ultimate way of understanding the problem. According to the distribution, $29.6 \%$ of the respondents strongly disagree that the meeting with the leaders by the government agencies on behalf of the affected is fair and inclusive, $27.4 \%$ disagreed, while $22.6 \%$ and $20.4 \%$ agreed and strongly agreed that meeting with the leaders by the government agencies on behalf of the affected is fair and inclusive. In some, $57 \%$ of the respondents negatively perceived the consultation with the leaders on behalf of the affected people in the region.

\section{Discussion of the Findings}

The discovery of oil in the Niger Delta region of Nigeria has been followed by a multidimensional conflict, which has become a lucrative opportunity for the merchants of death all over the world ranging from, the sellers of illegal weapons to the smugglers and political gladiators. At the centre of the conflict in the region, is the poor mass that neither genuinely benefits from the illegal crude smugglers nor from the government of Nigeria that is believed to be in charge of the management of the petroleum resources. The conflict in the region emanating from the struggle for the petroleum resources has paralysed other socio-economic activities of the inhabitants of the region. This has reflected the failure of the Nigerian government in meeting with the target of the Sustainable Development Goals [1] (Ending Poverty in all its Forms), Goal 2 (Ending Hunger, Achieve Food Security; Improved Nutrition and Promote Sustainable Agriculture), Goal 3 (Ensure Healthy Lives and Promote the Well-being for all at all Ages) and Goal 16 (Promotion of Peaceful and Inclusive Societies for Sustainable Development). While the conflict in the region and government insincerity has forced many families out of their domestic occupations, which is majorly farming and fishing there by creating poverty, hunger is the order of the day in the region while food security is alternative forgone in the face of federal government quest for oil wealth without environmental concern. The environmental wellbeing of the people in the region is totally out of discussion since such is seen as unprofitable venture to the interest of the multinational oil corporations and government of Nigeria.

Women were only empowered in the region via their domestic occupation hence the constant threat to this occupation technically defeated the idea of women empowerment in the region. More importantly, the promotion of peace and inclusive societies, which the sustainable development goals aims to actualize has been defeated as the federal government is more interested in the game of divide and rule, in approaching the indices of environmentally-related conflict in the region. The complication of the conflict in the Niger Delta 
region continued to show impact on the region as the government adopted the policy of sharing of the leftover wealth from the oil among the community leaders in the name of empowerment programme to abate the restiveness for the oil exploration to continue without, empirically verifying the affected and sustainable approach to unhook the inhabitants of the region from money-induced struggle. From our findings, 38\% of the respondents indicated that the government approach to the conflict in the Niger Delta region is very poor while $36.6 \%$ indicated that they found such as relatively good. Majority of the respondents $(74.6 \%)$ indicating that the effort the federal government started making for more than fifteen years now is not contextually relevant is a clear indication that the television announcements and other presentations of the federal government of Nigeria about the region is yet to reach the affected and the masses who are at the centre of the matter. From the study, $52.4 \%$ of the respondents indicated that affected individuals and groups have not benefited from the government programme aimed at the affected in the region on the incidents of environmental pollution and loss of occupation.

This showed the deep flaw of the government myopic and uninformed policy strategy in approaching environmentally related challenges in the region. This is affirmed by the respondents' position on the meeting with the leaders of the communities in the region by the federal government and other agencies. According to the finding, $57 \%$ of the respondents disagreed that meeting with the community leaders properly represented the interests of the affected members of the communities in the region. Due to the presence of corruption in the region, the leaders and other people who can control others have seen it as a lucrative opportunity. The leaders simply see their position as an opportunity of getting something from the government with the condition of their people. In sum, majority of the respondents (57.4\%) were of the view that the current approach to the environmentally related conflict in the region cannot bring a lasting solution to the problem. The surface analysis of the government effort in resolving the conflict in the region focus so much on the amount spent and the reports by the representatives of the people of the region however, the indigenous people of the region felt differently as the policy strategy has not shown any empirical relationship with the actual condition of the people in the region. According to the standardized coefficient values (Beta) of the logistic regression on support to the current government's approach in resolving environmental conflict in the Niger delta region and other variables, the program of the government to resolve environmental problems in the area contributed the highest value to the model explanatory power (.410) but in negative direction, followed by how long the people have witnessed oil related pollution in their areas (.393).

This is the indication that the dominant factors in the problem of the Niger Delta conflict is hinged on the realities the population is living with, and the value government attached to such realities. The two factors springing up among other factors in the model specifically indicates that, pollution has become part of their lives and has come to define their relationship with their environment, the federal government and the multinational oil corporations in the region. Government management of these factors in the policy development and implementation is likely to ensure the effectiveness of the policy. According to the t value, there is a positive correlation between only two variables among other included variables and respondents' support to the current government approach in resolving environmental conflict in Niger Delta region while there is negative relationship between support to the present approach to the problem in the region and the rest of the included variables in the model. In the model explaining attitude towards violent struggle and other variables in the region, the standardized coefficient values (Beta) showed that age contributed the highest value to the model explanatory power (.636), followed by the program of the government to resolve environmental problems in the area (.570). While almost all the included variables were correlated with attitude towards violent struggle, attitude towards violent struggle can be predicted by all the included variables except involvement in the mode of consultation by the government agencies seeking to resolve environmental conflict in the area (.074) and the type of people who benefits from the programs (.636). 
Table 2: Linear Regression on Attitude Towards Violent Struggle and Other Variables

\begin{tabular}{|c|c|c|c|c|c|c|c|c|}
\hline \multirow{3}{*}{$\begin{array}{l}\text { Model } \\
1 \text { (Constant) }\end{array}$} & \multicolumn{2}{|c|}{$\begin{array}{l}\text { Unstandardized } \\
\text { Coefficients }\end{array}$} & \multicolumn{3}{|l|}{$\begin{array}{l}\text { Standardized } \\
\text { Coefficients }\end{array}$} & \multicolumn{3}{|c|}{ Correlations } \\
\hline & B & Std. Error & Beta & $\mathbf{T}$ & Sig. & $\begin{array}{l}\text { Zero- } \\
\text { order }\end{array}$ & Partial & Part \\
\hline & .911 & .044 & & 20.613 & .000 & & & \\
\hline Age & .387 & .042 & .636 & 9.183 & .000 & .920 & .383 & .140 \\
\hline $\begin{array}{l}\text { How long the youth have witnessed oil } \\
\text { related pollution in their areas }\end{array}$ & -.356 & .060 & -.406 & -5.888 & .000 & .830 & -.257 & -.090 \\
\hline $\begin{array}{l}\text { Youth perception of government approach } \\
\text { to environmental pollution in the region }\end{array}$ & .223 & .052 & .225 & 4.273 & .000 & .866 & .190 & .065 \\
\hline $\begin{array}{l}\text { Involvement in the mode of consultation } \\
\text { by the government agencies seeking to } \\
\text { resolve environmental conflict in the } \\
\text { region }\end{array}$ & .121 & .067 & .108 & 1.792 & .074 & .791 & .081 & .027 \\
\hline $\begin{array}{l}\text { Youth perception of the meeting with the } \\
\text { leaders by the government agencies on } \\
\text { behalf of the affected people in the region }\end{array}$ & .205 & .052 & .221 & 3.958 & .000 & .893 & .176 & .060 \\
\hline $\begin{array}{l}\text { Type of people who benefits from the } \\
\text { programs }\end{array}$ & -.023 & .049 & -.021 & -.473 & .636 & .841 & -.021 & -.007 \\
\hline $\begin{array}{l}\text { The program of the government to resolve } \\
\text { environmental problems in the region }\end{array}$ & .352 & .043 & .570 & 8.216 & .000 & .891 & .348 & .125 \\
\hline $\begin{array}{l}\text { Youth perception of the government } \\
\text { specific activities in resolving the }\end{array}$ & -.338 & .055 & -.349 & -6.187 & .000 & .822 & -.269 & -.094 \\
\hline
\end{tabular}

Dependent Variable: Youth perception of violent struggle as the viable means of resolving the environmental problems in Niger Delta region

$\mathrm{R}=0.941$ (94.1\%), $\mathrm{R}^{2}=0.886(88.6 \%), \mathrm{F}$ value $=423.690$

Note: Result is significant at .05

The overall power of the model in explaining attitude to violent struggle is $94.1 \%$ ( $\mathrm{R}$ value), F. value (423.690) while the individual variables (independent) contained in the model contributed at various levels in the overall explanation. According to the standardized coefficient values (Beta), age contributed the highest value to the model explanatory power (.636), followed by the specific program of the government to resolve environmental problems in the area (.570). According to the t value, there is a positive correlation between all the included variables and attitude towards violent struggle save for four variables (how long the people have witnessed oil related pollution in their areas \& government specific activities in resolving the problems in their areas). At the significance level of .05 attitudes towards violent struggle can be predicted by all the included variables except involvement in the mode of consultation by the government agencies seeking to resolve environmental conflict in the area (.074). 
Table 3: Linear Regression on Youth Support to the Current Government's Approach in Resolving Environmental Conflict in the Niger Delta Region and Other Variables

\begin{tabular}{|c|c|c|c|c|c|c|c|c|}
\hline \multirow[b]{2}{*}{ Model } & \multicolumn{2}{|c|}{$\begin{array}{l}\text { Unstandardized } \\
\text { Coefficients }\end{array}$} & \multicolumn{2}{|l|}{$\begin{array}{l}\text { Standardized } \\
\text { Coefficients }\end{array}$} & \multirow[b]{2}{*}{ Sig. } & \multicolumn{2}{|c|}{ Correlations } & \multirow[b]{2}{*}{ Part } \\
\hline & B & $\begin{array}{l}\text { Std. } \\
\text { Error }\end{array}$ & Beta & $\mathbf{T}$ & & $\begin{array}{l}\text { Zero- } \\
\text { order }\end{array}$ & Partial & \\
\hline 1 (Constant) & .024 & .022 & & 1.124 & .262 & & & \\
\hline Age & -.055 & .021 & -.081 & -2.650 & .008 & .932 & -.119 & -.018 \\
\hline $\begin{array}{l}\text { How long the youth have witnessed oil } \\
\text { related pollution in their areas }\end{array}$ & .385 & .030 & .393 & 12.935 & .000 & .962 & .505 & .087 \\
\hline $\begin{array}{l}\text { Youth perception of government approach to } \\
\text { environmental pollution in the region }\end{array}$ & -.252 & .026 & -.228 & -9.814 & .006 & .932 & -.405 & -.066 \\
\hline $\begin{array}{l}\text { Involvement in the mode of consultation by } \\
\text { the government agencies seeking to resolve } \\
\text { environmental conflict in the region }\end{array}$ & .098 & .033 & .078 & 2.957 & .000 & .893 & -.132 & -.020 \\
\hline $\begin{array}{l}\text { Type of people who benefits from the } \\
\text { programs }\end{array}$ & -.023 & .049 & -.021 & -.473 & .636 & .841 & -.021 & -.007 \\
\hline $\begin{array}{l}\text { The program of the government to resolve } \\
\text { environmental problems in the region }\end{array}$ & -.282 & .021 & -.410 & -3.394 & .008 & .961 & -.518 & -.090 \\
\hline $\begin{array}{l}\text { Youth perception of the government specific } \\
\text { activities in resolving the problems in their } \\
\text { areas }\end{array}$ & -.303 & .027 & -.280 & -11.278 & .007 & .905 & -.454 & -.076 \\
\hline
\end{tabular}

Dependent Variable: Youth support to the current government's approach in resolving environmental conflict in the region

$\mathrm{R}=0.639(63.9 \%), \mathrm{R}^{2}=0.628(62.8 \%), \mathrm{F}$ value $=2.404$

Note: Result is significant at .005

The overall power of the model in explaining youth support to the current government's approach in resolving environmental conflict in the region is $63.9 \%$ ( $R$ value), F. value (2.404) while the individual variables (independent) contained in the model contributed at various levels in the overall explanation. According to the standardized coefficient values (Beta), The program of the government to resolve environmental problems in the area contributed the highest value to the model explanatory power $(-.410)$ but in negative direction, followed by how long the people have witnessed oil related pollution in their areas (.393). According to the $t$ value, there is a negative correlation between all the included variables and respondents' support to the current government approach in resolving environmental conflict in Niger Delta region save for two variables (how long the respondents have witnessed pollution and involvement in the mode of consultation by the government agencies). At the significance level of .05 supports to the current government approach in resolving environmental conflict in Niger Delta region can be predicted by only two variables such as how long the respondents have witnessed pollution and involvement in the mode of consultation.

\section{Conclusion}

The study has so far evaluated the environmentally related conflict in the Niger Delta region of Nigeria with focus on the government approach in resolving the challenge via Sustainable Development Goal programme. Even though the government and perhaps other organizations have put in some effort in tackling the problem, there seems to be some loopholes that have made the efforts so far appear as ineffective. In any case, the present study has revealed the latent force behind the ceaseless conflict and other environmentally related agitations in the region against the government and the multinational oil corporations. The underlying information from the present study indicates that the current approach to the resolution of environmentally induced conflicts/struggles in the Niger delta region lacks empirical validity in the face of realities in the region. Dynamic approach, empirically informed policies and reliable strategies for policy implementation are lacking in the region making the region, a conflict hub and a haven for militancy posture. Intimidating the inhabitants of the region with military and other security outfits can only offer a temporary 
relief [as the uncoordinated amnesty did] but will soon expire and give room for the agitations to take another dimension, which the federal government and even the United Nations may not be able to control without some level of collateral damage. In view of the findings the following recommendations are presented for the consumption of the policy makers in the federal, states and local governments in the region including, the nongovernmental organizations interested in bringing a lasting solution to the Niger Delta agitation issue.

There should be a dynamic approach to the policy initiation and implementation considering, the latest development and the current developmental needs of the people consultation on the needs of the people and implementation of the empirically informed policies should involve both the leaders as well as the members of the affected groups in order to diffuse the practice of middle. Government and other interested agencies ought to set up environmentally relevant infrastructures to encourage self-employment and productivity in the region, to gradually neutralize the mind of the youth from dependency on the gift from the government and other organizations. The consultations in the region, the policy initiation, structure of the policy and its implementation should accord priority to the basic needs and infrastructures for the youth in order to develop self-sustaining mechanism to focus the youth to their future order than being tools of conflict in hands of the leaders basically, for the government and other agencies to develop and successfully implement people oriented and sustainable development policies, there is a need for the collection of up to date empirical information from the population.

\section{References}

Adalikwu, J. (2007). Globalization and the Uneven Application of International Regulatory Standard: The Case of Oil Exploration in Nigeria. PhD Thesis, University of Saskatchewan, Saskatoon.

AGUNOBI, K. N., OBIENUSI, E. A. \& ONUOHA, D. C. (2014). An Investigation of the Pattern and Environmental Impact of Oil Spillage in Etche Local Government Area of Rivers State, Nigeria. African Journal on Conflict Resolution, 4(16), 124-137.

Ajero, et al. (2016). Academe-Industry Partnership: Basis for Enhanced Learning Guide in the New Science General Education Course. Asia Pacific Journal of Multidisciplinary Research, 4(4), 96-102.

Ajodo-Adebanjoko, A. (2017). Towards ending conflict and insecurity in the Niger Delta region: A collective non-violent approach. African Journal on Conflict Resolution, 17(1), 9-27.

Akinade, E. A. (2005). Dictionary of Guidance \& Counseling: Counseling Psychology Lagos: Olu-Akin publishers.

Amnesty International. (2009). Nigeria: petroleum, pollution and poverty in the Niger delta - report. London: Amnesty International Publications Index number: AFR 44/017/2009

Bernstein, D. A., Clark-Stewart, A., Penner, L. A., Roy, E. J. \& Wickens, C. D. (2000). Psychology, New York: Houghton Mifflin.

Isike, C. (2005). Federal, state and resource control in Nigeria, Benin: F Parker Publishing

Dollard, J., Miller, N. E., Doob, L. W., Mowrer, O. H. \& Sears, R. R. (1939). Frustration and aggression. New Haven: CT, US.

Ede, P. N. \& Edokpa, D. O. (2015). Regional air quality of the Nigeria's Niger delta. Open Journal of Air Pollution, $4,7-15$.

Enetimi, I. S. \& Izah, S. C. (2017). A Review of Impacts of Gas Flaring on Vegetation and Water Resources in the Niger Delta Region of Nigeria. International Journal of Economy, Energy and Environment, 2(4), 48-55.

Federal Republic of Nigeria. (2017). Implementation of the SDGs A National Voluntary Review. Abuja: Federal Government Publication.

Ibeanu, 0. (2006). Civil society and conflict management in the Niger Delta: Scoping gaps for policy and advocacy. Lagos: CLEEN Foundation.

Kadafa, A. A. (2012). The Environmental Impacts of Oil Exploration and Exploitation in the Niger Delta of Nigeria. Global Journal of science frontier, environment and earth sciences, 13(3), 19-28.

Luqman, S. (2011). Democratic Governance and the Management of Oil conflict in Nigeria's Niger Delta: Policy options and challenges. African Journal of Political Science and International Relations, 5(2), 83-91.

Nduka, J. K., Orisakwe, O. E. \& Ezenwa, T. E. (2009). Effect of effluents from Warri refinery and petrochemical company on water and soil qualities of contiguous host and impacted on communities of Delta State, Nigeria. The Open Environmental and Toxicology Journal, 1, 11-17. 
Nuhu, M. S. \& Ali, D. (2015). Assessment of Public Participation in resolving Environmental Problems in Delta State, Nigeria. World Environment, 5(1), 28-37.

Nworu, O. C. (2017). Ogoni clean-up, Remediation and Satisfactory Environment Favorable to Its Development: Obligations of the Nigerian State. World Environment, 7(2), 31-41.

OBAFEMI, A. A., ELUDOYIN, O. S. \& AKINBOSOLA, B. M. J. (2012). Public Perception of Environmental Pollution in Warri, Nigeria. Appl. Sci. Environ. Manage, 16(3), 233-240.

Okumagba, P. O. (2012). Militancy and Human Rights Violation in Niger Delta. International Review of Social Sciences and Humanities, 3(2), 29-37.

Onwubiko, O. F., Azizan, A., Khairuddin, I. \& Jamilah, O. (2013). International Journal of Social and Behavioural Sciences, 1(6), 122-129.

Ortese, P. T. (2004). Counseling against political thuggery in Nigeria's nascent Democracy. Journal of Counseling \& Development: Counseling Association of Nigeria (CASSON) Benue State chapter, 1(1), 133142.

Osarenren, N. (2000). Psychological violence against women and socio-economic class: Implication for Counseling. Journal of Counseling Association of Nigeria (CASSON), 18(2), 367-371.

Schaeter, R. T. \& Lamm, R. P. (1998). Sociology. New York: McGraw-Hill Company.

Shehu, N. M. \& Ali, D. (2015). Assessment of the Public Participation in Solving Environmental Problems in Delta State, Nigeria. World Environment, 5(1), 28-38.

Shell. (1999). People and the Environment: Annual Report Lagos: SPDC.

Steiner, R. (2008). Double Standards? International Standards to prevent and control pipeline oil Spills, Compared with Shell practices in Nigeria. A report submitted to Friends of the Earth, Netherlands.

Ukeje, C. (2001). Youths, Violence and the Collapse of Public Order in the Niger Delta. Africa Development, $1(2), 337-366$.

UNDP. (2017). Niger Delta Human Development Report.

UNDP. (2006). Niger Delta Human Development Report. Abuja: UNDP

UNEP. (2011). Environmental Assessment of Ogoni land. UN Environment Programme 2011.

United Nations Environment Programme. (2011). Environmental Assessment of Ogoniland Report. Nairobi: United Nations Environmental Programme

Yakubu, O. H. (2017). Addressing Environmental Health Problems in Ogoniland through Implementation of United Nations Environmental Program Recommendation Environmental Management Strategies. Environments, 4(28), 2-19.

Zabbey, N. (2009). Petroleum and pollution - how does that impact human rights? Stockholm Amnesty International. 